\title{
The efficient $o$-benzenedisulfonimide catalysed synthesis of benzothiazoles, benzoxazoles and benzimidazoles
}

\author{
Margherita Barbero, Silvano Cadamuro, and Stefano Dughera* \\ Dipartimento di Chimica dell'Università di Torino, Via Pietro Giuria 7, 10125 Torino, Italy \\ E-mail: stefano.dughera@unito.it
}

\begin{abstract}
$o$-Benzenedisulfonimide has been used to efficiently catalyse the reaction between 2-aminothiophenol, 2-aminophenol, $o$-phenylenediamine and various ortho esters (28 examples; average yield $90 \%$ ) or aldehydes (17 examples; average yield $72 \%$ ) giving the corresponding benzofused azoles in excellent yields. Reaction conditions were very simple. In addition, other carboxylic acid derivatives have been tested and gave good results. The catalyst was easily recovered and reused.
\end{abstract}

Keywords: Green chemistry, homogeneous catalysis, heterocycles, recyclable catalyst, disulfonimide

\section{Introduction}

Benzoxazoles, benzimidazoles, benzothiazoles and their derivatives are important classes of molecules in several field of organic chemistry. ${ }^{1}$ In particular, they are a common heterocyclic scaffold in biologically active and medicinally significant compounds ${ }^{2 a}$ and are found in a large variety of natural products. ${ }^{2 b}$ Moreover, these groups of heterocyclic compounds exhibit a wide range of pharmacological properties, which include antiviral, ${ }^{3}$ antimicrobial, ${ }^{4}$ antitumor, ${ }^{5}$ antibiotic, ${ }^{6}$ antifungal, ${ }^{7}$ anticonvulsant, ${ }^{8}$ anti-inflammatory activity ${ }^{9}$ and many others. ${ }^{10,11}$ Their use in the field of advanced materials is also worthy of note. ${ }^{12}$

Because of the number and the significance of their applications, many synthetic methods have been reported for the preparation of these compounds over the years. ${ }^{1 b, 1 d, 2 a}$ In brief, there are two commonly used approaches for their construction, both of which employ 2-aminothiophenol, 2-aminophenol, or $o$-phenylenediamine as the starting substrates. The first involves the coupling of the appropriate aminoaromatic with a carboxylic derivative under strongly acidic conditions. The second one works via the reaction of the appropriate aminoaromatic with an aldehyde followed by oxidative cyclization of the imine intermediate. However, these methods often suffer from drawbacks, such as the use of strongly acidic conditions, toxic catalysts (often 
not recoverable and reusable), and long reaction times, low products yields, troublesome workup, and the need to use solvents and reagents in large excess. ${ }^{13}$

Therefore, due to the importance of these heterocycles, the literature has provided new, efficient and environmentally benign methods for their preparation over the last few years. ${ }^{2 a, 10-14}$ Moreover, the numerous and important biological applications that exist for benzo derivatives of azoles have been the motivation for renewed efforts in the search for novel derivatives with improved biological activity and diverse applications in the pharmaceutical industry. ${ }^{11}$ We have recently reported the use of $o$-benzenedisulfonimide ${ }^{15 a}(\mathbf{1}$; Figure 1$)$ in catalytic amounts as a Brønsted acid in several acid-catalyzed organic reactions under very mild and selective conditions. ${ }^{15 b, c}$ The catalyst was easily recovered and purified, ready to be used in further reactions, with economic and ecological advantages. Furthermore, $\mathbf{1}$ has already been advantageously used as a catalyst in the preparation of other important biologically active compounds such as quinolines ${ }^{15 \mathrm{~d}}$ and tetrahydroisoquinolines. ${ }^{15 \mathrm{e}}$

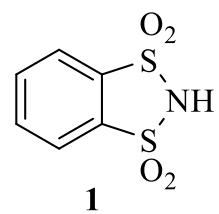

Figure 1. $o$-benzenedisulfonimide (1).

\section{Results and Discussion}

In this paper we report a comprehensive study of the reactions between 2-aminothiophenol (2a), 2-aminophenol (2b), o-phenylenediamine (2c), and some their derivatives. with various carboxylic acid derivatives 3-5, 8 or aldehydes 6 (and ketones 7, in order to obtain benzothiazolines or benzoxazolines) in the presence of catalytic amounts of $\mathbf{1}$ to provide benzothiazoles $\mathbf{9}$, benzoxazoles 10 and benzimidazoles 11 (Scheme 1).

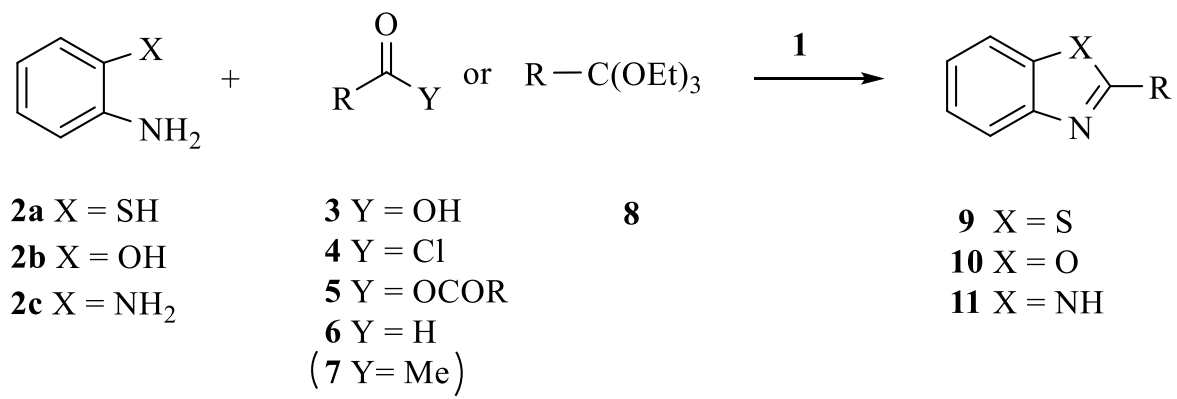

Scheme 1. Reaction between 2-aminoaromatics $\mathbf{2}$ and carboxylic 3-5 or carbonyl derivatives $\mathbf{6}$, 7 catalyzed by 1 . 
To begin with, we studied the reaction between $\mathbf{2 a}$ and four carboxylic derivatives, namely benzoic acid (3a), benzoyl chloride (4a), benzoic anhydride (5a) and triethyl orthobenzoate (8a) in the presence of catalytic amounts of $\mathbf{1}(5 \mathrm{~mol}-\%)$ under neat conditions and in equimolar amounts. The results are reported in Table 1. The reaction did not occur with $\mathbf{3 a}$ (Table 1, entry 1) and occurred only in part with 5a (Table 1, entry 3). However, 4a (Table 1, entry 2; the formation of the by-product $\mathrm{HCl}$ did not impede the progress of the reaction) and 8a (Table 1, entry 4) gave the target compound 2-phenylbenzothiazole (9a) in very good yields. It must be stressed that the presence of a solvent (THF or $\mathrm{CH}_{2} \mathrm{Cl}_{2}$ ) slowed the reactions and decreased the yields (Table 1 , entry 4 , note d).

Table 1. Trial reactions between 2a-c and various carboxylic derivatives

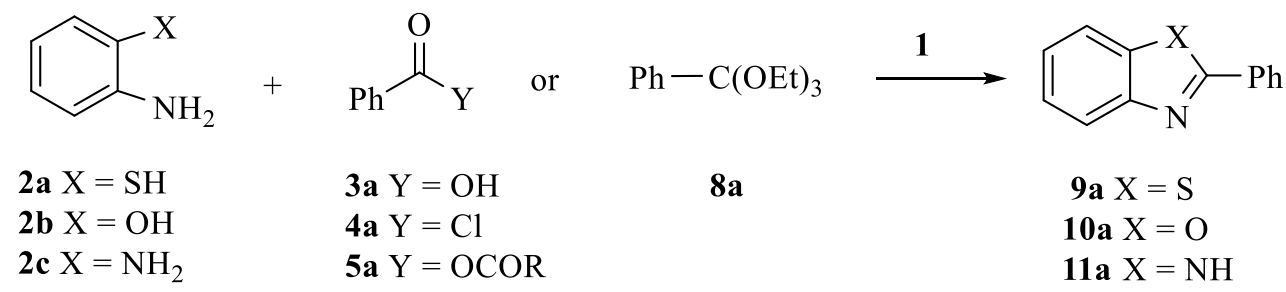

\begin{tabular}{|c|c|c|c|c|}
\hline Entry & Reactant & Temp $\left({ }^{\circ} \mathrm{C}\right)$ & Time (h) & Yield $(\%)$ of $\mathbf{9 a}, \mathbf{1 0 a}, \mathbf{1 1} \mathbf{a}^{\mathrm{a}, \mathrm{b}}$ \\
\hline 1 & $2 a ; 3 a$ & 50 & 24 & - \\
\hline 2 & $2 a ; 4 a$ & 50 & 24 & $9 a ;{ }^{c}$ \\
\hline 3 & $2 a ; 5 a$ & 50 & 2 & $9 a ; 87$ \\
\hline 4 & $2 a ; 8 a$ & r.t. & 1.5 & $9 \mathbf{a} ; 90^{\mathrm{d}}$ \\
\hline 5 & $2 b ; 4 a$ & 50 & 24 & $\mathrm{e}$ \\
\hline 6 & $2 b ; 8 \mathbf{a}$ & r.t. & 3 & $\mathbf{1 0 a} ; 93^{\mathrm{d}}$ \\
\hline 7 & $2 c ; 4 a$ & 50 & 24 & $\mathrm{f}$ \\
\hline 8 & $2 c ; 5 a$ & 50 & 24 & 11a; 87 \\
\hline 9 & $2 c ; 8 a$ & r.t. & 3 & $11 a ; 92^{d}$ \\
\hline
\end{tabular}

${ }^{a}$ Yields refer to the pure products. ${ }^{b}$ Reactants $\mathbf{2 a}$ and $\mathbf{3 a - 5 a}, \mathbf{8 a}$ were in equimolar amounts (10 mmol). The reactions were carried out in neat conditions and in the precence of 5 mol- $\%$ of $1 .^{c}$ After 24 hours, 9a and several by-products were detected by GC-MS analyses. ${ }^{\mathrm{d}}$ The reaction did not occur without $\mathbf{1}$. In the presence of an organic solvent (THF or $\left.\mathrm{CH}_{2} \mathrm{Cl}_{2}\right)$ the yields of 9a, 10a, 11a were lower. ${ }^{\mathrm{e}}$ The main product of the reaction was $N$-(2-hydroxyphenyl)benzamide (17a), MS, $m / z(\%)=213(25)\left[\mathrm{M}^{+}\right], 105(100), 77(35)$. Only traces of 10a were detected on GC-MS analyses, MS, $m / z(\%)=195(100)\left[\mathrm{M}^{+}\right], 167(15), 63(20)$. On heating to $120{ }^{\circ} \mathrm{C}$ the main product was 2-(benzamidophenyl)phenyl benzoate (18a), MS, $m / z(\%)=317(15)\left[\mathrm{M}^{+}\right], 105$ (100), 77(12). ${ }^{\mathrm{f}}$ The sole product of the reaction was $N$-(2-aminophenyl)benzamide (21a), MS, $\mathrm{m} / \mathrm{z}(\%)=212(55)\left[\mathrm{M}^{+}\right], 194(100), 105(100), 77(35)$. To detect 21a it was necessary to treat the crude residue with aqueous $\mathrm{NaOH}(10 \%)$. 
When comparing the two reagents, it can be seen that the use of $8 \mathbf{a}$ was certainly preferable because of the formation of $\mathrm{EtOH}$ rather than $\mathrm{HCl}$ as a by-product. In addition, the reactions with 8a were carried out at r.t. while it was necessary to heat the reaction to $50{ }^{\circ} \mathrm{C}$ when using $4 \mathbf{a}$. However, a greater variety of acyl chlorides are commercially available. For this reason, it was also decided to study the reaction between $\mathbf{2 a}$ and its derivative $\mathbf{2 d}$ and a selected number of $\mathbf{4}$ and 8, both aromatic and aliphatic, (4: 7 examples, Table 2, entries 1-7. Average yield 71\%. 8: 8 examples. Table 2, entries 8-15. Average yield 90\%) gave the corresponding 9 in excellent yields. Reaction conditions, especially in the presence of $\mathbf{8}$ were very simple, mild and efficient (Scheme 2, where is also reported the mechanism of the reaction).

Table 2. Reactions between $\mathbf{2 a}, \mathrm{d}$ and $\mathbf{4}$ or 8

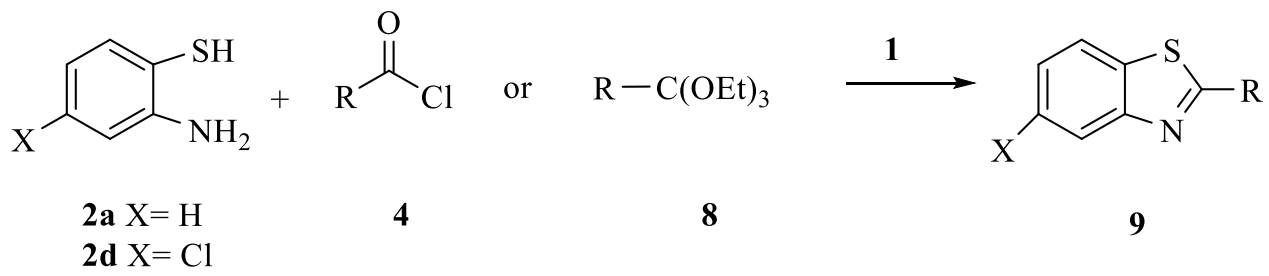

\begin{tabular}{|c|c|c|c|c|}
\hline Entry & $\mathrm{R}$; reactant 4 or 8 & $\mathrm{R}$; product 9 & Time $(\mathrm{h})$ & Yield $(\%)^{\mathrm{a}}$ \\
\hline 1 & $\mathrm{Ph} ; \mathbf{4 a}$ & $\mathrm{Ph} ; \mathbf{9 a}$ & 2 & $87^{\mathrm{b}}$ \\
\hline 2 & $4-\mathrm{MeOC}_{6} \mathrm{H}_{4} ; \mathbf{4 b}$ & $4-\mathrm{MeOC}_{6} \mathrm{H}_{4} ; \mathbf{9 b}$ & 2.5 & $83^{\mathrm{b}}$ \\
\hline 3 & $4-\mathrm{ClC}_{6} \mathrm{H}_{4} ; \mathbf{4 c}$ & $4-\mathrm{ClC}_{6} \mathrm{H}_{4} ; 9 \mathbf{c}$ & 2.5 & $80^{\mathrm{b}}$ \\
\hline 4 & $4-\mathrm{NO}_{2} \mathrm{C}_{6} \mathrm{H}_{4} ; \mathbf{4 d}$ & $4-\mathrm{NO}_{2} \mathrm{C}_{6} \mathrm{H}_{4} ; 9 d$ & 3 & $76^{\mathrm{b}}$ \\
\hline 5 & $\mathrm{Me} ; \mathbf{4 e}$ & $\mathrm{Me} ; 9 \mathrm{e}$ & 3.5 & $81^{\mathrm{b}}$ \\
\hline 6 & $c-\mathrm{C}_{6} \mathrm{H}_{11} ; \mathbf{4 f}$ & $c-\mathrm{C}_{6} \mathrm{H}_{11} ; \mathbf{9 f}$ & 2.5 & $53^{\mathrm{b}, \mathrm{d}}$ \\
\hline 7 & $t-\mathrm{C}_{4} \mathrm{H}_{9} ; \mathbf{4 g}$ & $t-\mathrm{C}_{4} \mathrm{H}_{9} ; \mathbf{9 g}$ & 3 & $42^{\mathrm{b}, \mathrm{d}}$ \\
\hline 8 & $\mathrm{Ph} ; \mathbf{8 a}$ & $\mathrm{Ph} ; \mathbf{9 a}$ & 1.5 & $90^{c}$ \\
\hline 9 & $4-\mathrm{MeOC}_{6} \mathrm{H}_{4} ; \mathbf{8 b}$ & $4-\mathrm{MeOC}_{6} \mathrm{H}_{4} ; \mathbf{9 b}$ & 1 & $90^{c}$ \\
\hline 10 & $4-\mathrm{ClC}_{6} \mathrm{H}_{4} ; \mathbf{8 c}$ & $4-\mathrm{ClC}_{6} \mathrm{H}_{4} ; 9 \mathrm{c}$ & 1 & $92^{c}$ \\
\hline 11 & $4-\mathrm{NO}_{2} \mathrm{C}_{6} \mathrm{H}_{4} ; \mathbf{8 d}$ & $4-\mathrm{NO}_{2} \mathrm{C}_{6} \mathrm{H}_{4} ; 9 \mathbf{9}$ & 1.5 & $91^{\mathrm{c}}$ \\
\hline 12 & $\mathrm{Me} ; \mathbf{8 e}$ & Me; 9e & 3 & $90^{c}$ \\
\hline 13 & $\mathrm{PhCH}_{2} ; \mathbf{8 f}$ & $\mathrm{PhCH}_{2} ; \mathbf{9 h}$ & 2 & $90^{c}$ \\
\hline 14 & $\mathrm{Ph} ; \mathbf{8 a}^{\mathrm{e}}$ & $\mathrm{Ph} ; 9 \mathbf{9}(\mathrm{X}=\mathrm{Cl})$ & 1.5 & $90^{c}$ \\
\hline 15 & $\mathrm{Me} ; \mathbf{8 e}^{\mathrm{e}}$ & $\mathrm{Me} ; \mathbf{9 j}(\mathrm{X}=\mathrm{Cl})$ & 2 & $86^{c}$ \\
\hline
\end{tabular}

${ }^{a}$ Yields refer to the pure products. ${ }^{b}$ Reactants were in equimolar amounts $(10 \mathrm{mmol})$. The reactions were carried out in neat conditions at $50{ }^{\circ} \mathrm{C}$ and in the presence of 5 mol-\% of 1. ${ }^{\mathrm{c}}$ Reactants were in equimolar amounts $(10 \mathrm{mmol})$ in neat conditions. The reactions were carried out in neat conditions at r.t. and in the presence of 5 mol- $\%$ of $1{ }^{d}$ Products $9 \mathbf{f}$ and $9 \mathrm{~g}$ were 
purified by flash column chromatography on silica gel, $\left(\mathrm{CH}_{2} \mathrm{Cl}_{2}-\mathrm{MeOH} 9.8: 0.2\right)$. ${ }^{\mathrm{e}}$ The other reactant was $\mathbf{2 d}$.

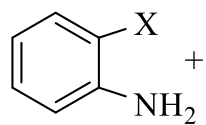

2<smiles>[R]C(=O)OCC</smiles>

8<smiles>[R]c1[X]c2ccccc2n1</smiles>

9<smiles>[R]c1[X]c2ccccc2n1</smiles>

$\mathrm{R}-\mathrm{C}(\mathrm{OEt})_{3}$

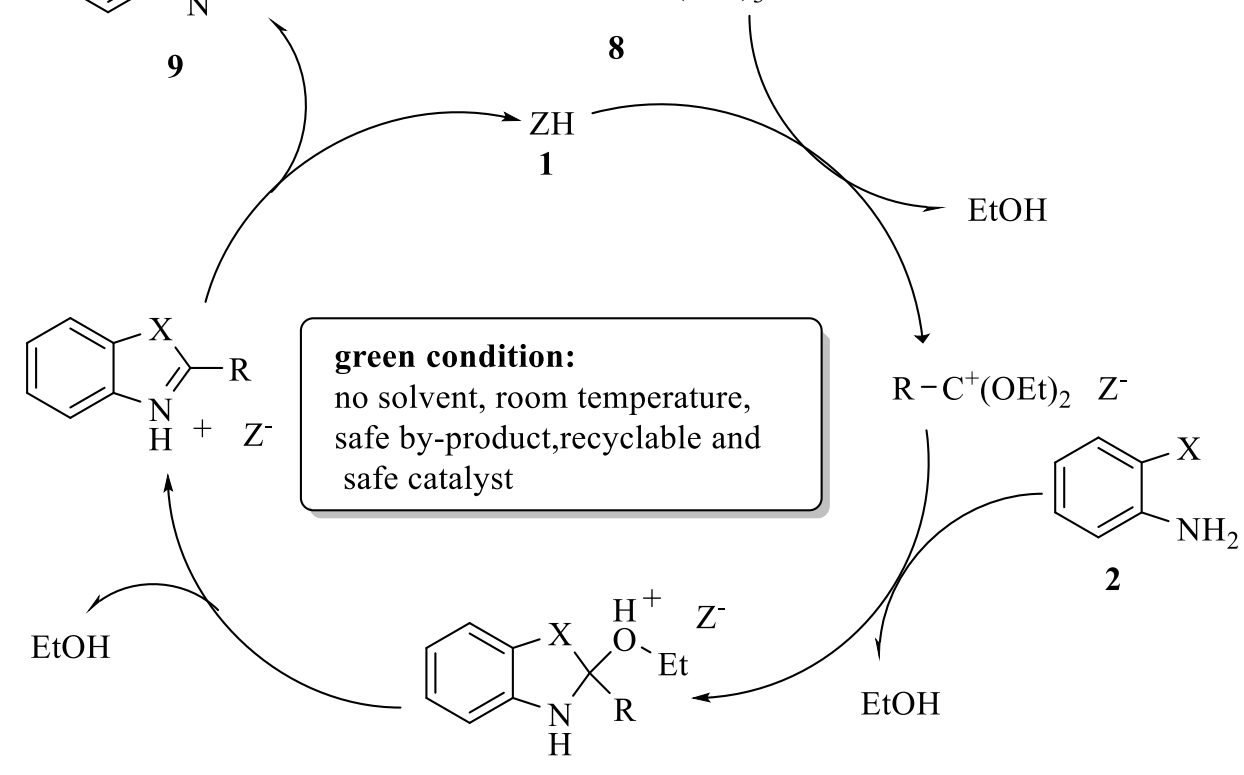

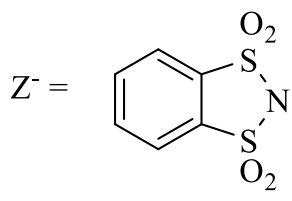

Scheme 2. Reaction between $\mathbf{2}$ and $\mathbf{8}$.

When compounds 9 were solid (generally those that have an aromatic group bonded to the benzothiazole ring) (Table 2, entries 1-4 and 8-11,14) the work-up was very easy and convenient. It was sufficient to add $\mathrm{H}_{2} \mathrm{O}$ to the crude residue, filter and wash the resulting solid with additional $\mathrm{H}_{2} \mathrm{O}$ and a small amount of PE on a Buchner funnel. In other cases (Table 2, entries 5-7, 12, 13, 15) a fast extraction with a small amount of solvent (EtOAc) was necessary.

Furthermore, 1 was recovered in excellent yield (91\%) simply by the evaporation of the aqueous washings as reported in the Experimental Section. The recovered $\mathbf{1}$ was reused as the catalyst in four further consecutive reactions between $\mathbf{2 a}$ and $\mathbf{8 a}$. The results are listed in Table 3: the reaction time increased over the course of the different reactions, however, the yields of $9 \mathbf{a}$ and the recovery of $\mathbf{1}$ were always good.

We also performed the reaction between $2 \mathbf{a}$ and $8 \mathbf{a}$ in the presence of 5 mol-\% of eight different acid catalysts under neat conditions to compare and contrast them with the catalytic 
activity of 1 (Table 4). The results showed that only with 2,4-dinitrobenzenesulfonic acid both the reaction time and the yield were similar to that obtained with 1 (Table 4, entry 8). However, it was not easily recovered and reused.

Table 3. Consecutive runs with recovered 1

\begin{tabular}{cccc}
\hline Entry & Time $(\mathrm{h})$ & Yield $(\%)$ of $\mathbf{9} \mathbf{a}^{\mathrm{a}}$ & Recovery $(\%)$ of $\mathbf{1}^{\mathrm{b}}$ \\
\hline 1 & 1.5 & $90^{\mathrm{c}}$ & $91\left(100 \mathrm{mg}^{\mathrm{d}}\right)$ \\
2 & 1.5 & 88 & $92\left(92 \mathrm{mg}^{\mathrm{e}}\right)$ \\
3 & 2 & 87 & $87\left(80 \mathrm{mg}^{\mathrm{f}}\right)$ \\
4 & 2.5 & 85 & $86\left(69 \mathrm{mg}^{\mathrm{g}}\right)$ \\
5 & 2.5 & 84 & $84(58 \mathrm{mg})$ \\
\hline
\end{tabular}

${ }^{a}$ Yields refer to the pure product. ${ }^{\mathrm{b}}$ The amount (in $\mathrm{mg}$ ) of recovered $\mathbf{1}$ is reported in brackets. ${ }^{\mathrm{c}}$ The reaction was performed with $10 \mathrm{mmol}$ of $\mathbf{2 a}$ and $\mathbf{8 a}$ and $5 \mathrm{~mol}-\%$ of $\mathbf{1}(110 \mathrm{mg}, 0.5 \mathrm{mmol}) .{ }^{\mathrm{d}}$ Recovered $\mathbf{1}$ was used as a catalyst in entry $2 .{ }^{\mathrm{e}}$ Recovered $\mathbf{1}$ was used as catalyst in entry $3 .{ }^{\mathrm{f}}$ Recovered $\mathbf{1}$ was used as a catalyst in entry $4{ }^{\mathrm{g}}$ Recovered $\mathbf{1}$ was used as a catalyst in entry 5.

Table 4. 2-Phenylbenzothiazole synthesis using other acid catalysts

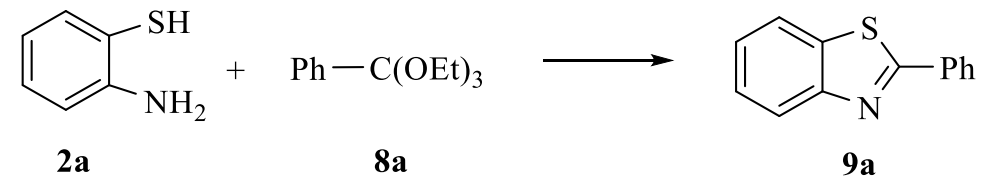

\begin{tabular}{cccc}
\hline Entry & Acid Catalyst & Time $(\mathrm{h})$ & Yield $(\%)$ of $\mathbf{5 a}^{\mathrm{a}, \mathrm{b}}$ \\
\hline 1 & $\mathrm{AlCl}_{3}$ & 24 & $\mathrm{c}$ \\
2 & $\mathrm{HCl} \mathrm{37 \%}$ & 24 & $\mathrm{c}$ \\
3 & $\mathrm{HBF}_{4} \cdot \mathrm{Et}_{2} \mathrm{O} 54 \%$ & 7 & 85 \\
4 & $\mathrm{HCOOH}$ & 7 & 90 \\
5 & $\mathrm{MeSO}_{3} \mathrm{H}$ & 5 & 91 \\
6 & $\mathrm{NH}_{2} \mathrm{SO}_{3} \mathrm{H}$ & 8 & 84 \\
7 & $4-\mathrm{MeC}_{6} \mathrm{H}_{4} \mathrm{SO}_{3} \mathrm{H}$ & 5 & 90 \\
8 & $2,4-\left(\mathrm{NO}_{2}\right)_{2} \mathrm{C}_{6} \mathrm{H}_{3} \mathrm{SO}_{3} \mathrm{H}$ & 2 & 91 \\
\hline
\end{tabular}

${ }^{a}$ Yields refer to the pure products. ${ }^{b}$ Reactants $\mathbf{2 a}$ and $\mathbf{8 a}$ were in equimolar amounts (5 mmol). The reactions were carried out in neat conditions at r.t. and in the precence of $5 \mathrm{~mol}-\%$ of catalysts. ${ }^{\mathrm{c}}$ After 24 hours the reaction was not complete. GC-MS analyses showed the presence of starting products $\mathbf{2 a}$.

Aldehydes 6 were also used in place of carboxylic derivatives 4 and 8 (Scheme 3) in order to further explore the synthetic usefulness of $\mathbf{1}$ in the synthesis of benzothiazoles $\mathbf{9}$. In a 
preliminary test, benzaldehyde (6a) and $\mathbf{2 a}$ were reacted. The reaction was heated to $50{ }^{\circ} \mathrm{C}$ in neat conditions and in the presence of catalytic amounts of 1 ( 5 mol-\%). After 1 hour, the GCMS analyses showed the presence of three products: 9a, benzothiazoline 13a (or/and imine 12a) and a compound which had a mass spectrum compatible with the structure 16a, shown in Scheme 3. Most probably, 1 favored the nucleophilic attack of the SH group of 12a towards the carbonyl group of $\mathbf{6 a}$ and then the dehydration of intermediate 14a. The adduct 15a furnished 16a, perhaps due to a hydride transfer from 13a (Scheme 3).

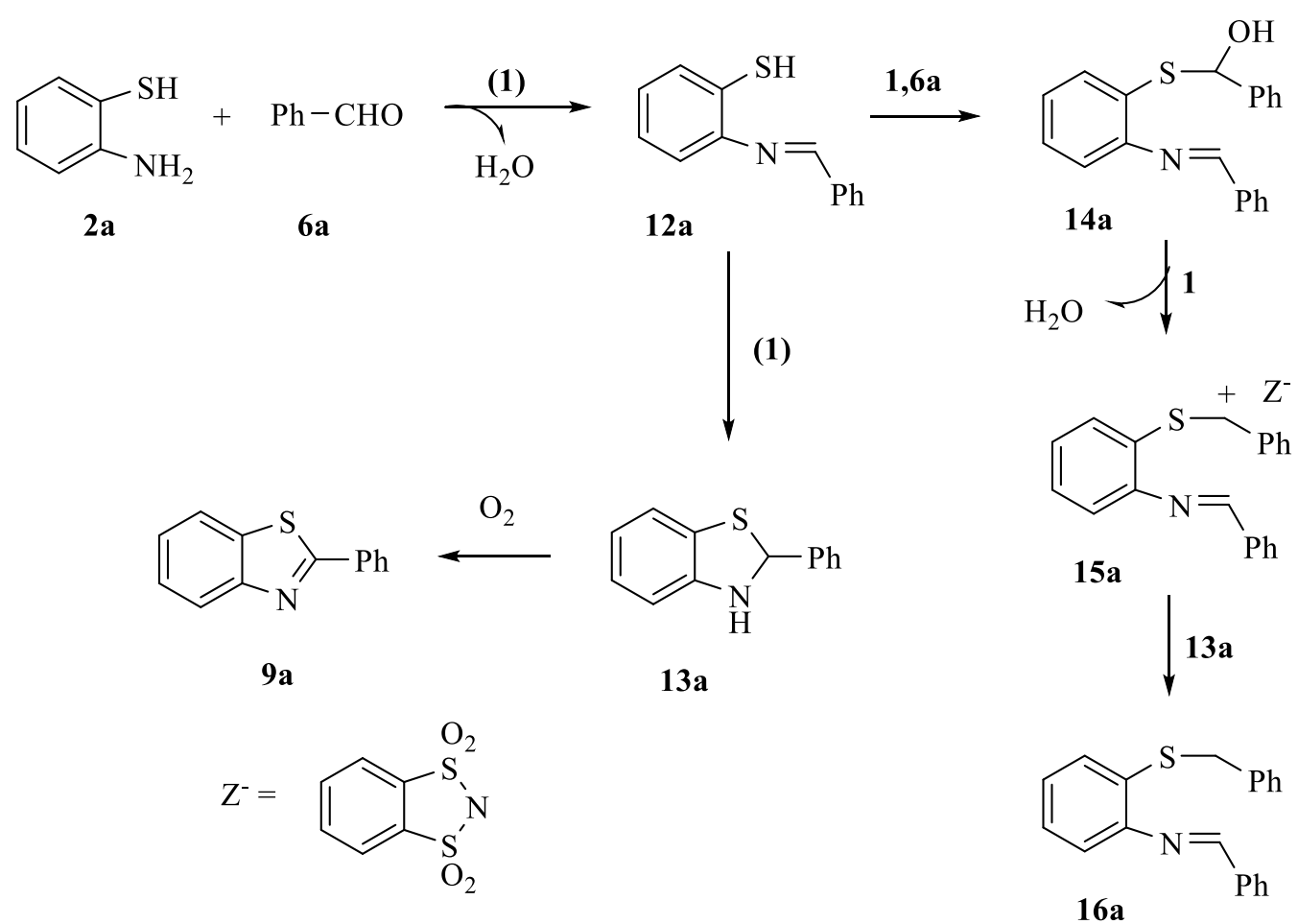

Scheme 3. Reaction between $2 \mathbf{a}$ and $\mathbf{6 a}$.

After 3 hours, 13a completely disappeared due to its air oxidation to 9a. In order to avoid the formation of by-product $\mathbf{1 6 a}$, the reaction conditions were modified. In this version, $\mathbf{2 a}$ and 6a were initially heated to $50{ }^{\circ} \mathrm{C}$ in neat conditions. After 1 hour, the GC-MS analyses only showed the presence of 9a and 13a. Indeed, the ${ }^{1} \mathrm{H}-\mathrm{NMR}$ analyses showed the presence of a third compound, namely the imine 12a. In fact, two singlets could be found among the other peaks; the first $\left(\delta_{\mathrm{H}} 6.36\right)$ is due to 13a and the second $\left(\delta_{\mathrm{H}} 8.51\right)$ is due to 12a. After about 36 hours of heating to $50{ }^{\circ} \mathrm{C}, 9 \mathbf{a}$ was obtained as the only product in fairly good yields (73\%). After 1 hour of heating (when $\mathbf{2 b}$ is no longer present) the addition of $\mathbf{1}$ (5 mol-\%) allowed us to obtain 9a in considerably less time (3 hours) and in a higher yield (88\%. Table 5, entry 1). Evidently, the protonation of $\mathbf{1 2 a}$ by $\mathbf{1}$ greatly facilitated the internal nucleophilic attack of SH group. On these grounds, ten aldehydes $\mathbf{6}$, both aliphatic and aromatic, were reacted with $\mathbf{2 a}$ with excellent results (average yield 86\%) which are reported in Table 5, (entries 1-10). Therefore, 6 (compounds readily commercially available and easily handled) can also be advantageously used 
as an alternative to $\mathbf{4}$ and $\mathbf{8}$ in the synthesis of $\mathbf{2}$. Benzothiazoline 13c was easily obtained after reacting $\mathbf{2 a}$ with acetone $\mathbf{7 b}$ (Table 5, entry 12 ).

Table 5. Reactions between $\mathbf{2 a}, \mathbf{2 b}, \mathbf{2 c}$ and aldehydes $\mathbf{6}$ or ketones 7

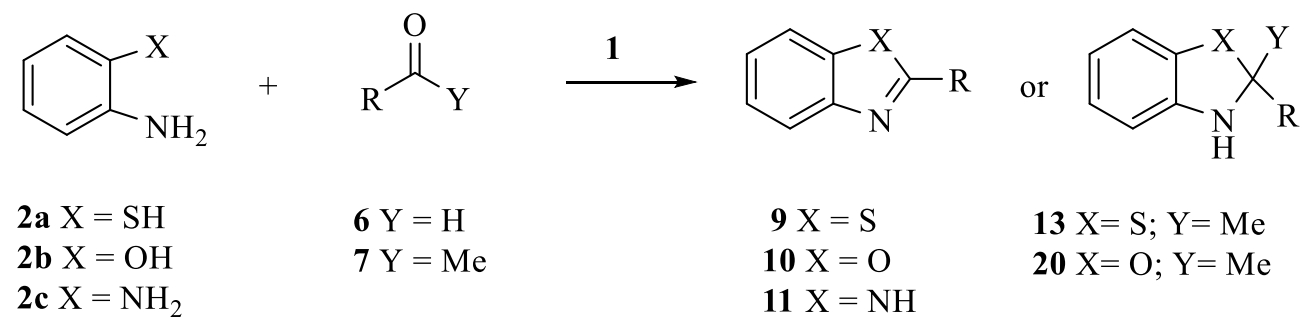

\begin{tabular}{|c|c|c|c|c|c|}
\hline Entry & Reactant 2 & R; reactant 6 or 7 & R; product $9, \mathbf{1 3}$ or $\mathbf{2 0}$ & Time (h) & Yield $(\%)^{\mathrm{a}, \mathrm{b}}$ \\
\hline 1 & $\mathbf{2 a}$ & $\mathrm{Ph} ; \mathbf{6 a}$ & $\mathrm{Ph} ; \mathbf{9 a}$ & 3 & 88 \\
\hline 2 & $\mathbf{2 a}$ & $2-\mathrm{MeOC}_{6} \mathrm{H}_{4} ; \mathbf{6 b}$ & $2-\mathrm{MeOC}_{6} \mathrm{H}_{4} ; \mathbf{9 k}$ & 4 & 84 \\
\hline 3 & $\mathbf{2 a}$ & $3-\mathrm{MeOC}_{6} \mathrm{H}_{4} ; \mathbf{6 c}$ & $3-\mathrm{MeOC}_{6} \mathrm{H}_{4} ; 9 \mathrm{I}$ & 3.5 & 84 \\
\hline 4 & $2 \mathbf{a}$ & $4-\mathrm{MeOC}_{6} \mathrm{H}_{4} ; \mathbf{6 d}$ & $4-\mathrm{MeOC}_{6} \mathrm{H}_{4} ; \mathbf{9 b}$ & 2.5 & 87 \\
\hline 5 & $2 \mathbf{a}$ & $4-\mathrm{ClC}_{6} \mathrm{H}_{4} ; \mathbf{6 e}$ & $4-\mathrm{ClC}_{6} \mathrm{H}_{4} ; 9 \mathrm{c}$ & 3.5 & 90 \\
\hline 6 & $2 \mathbf{a}$ & $4-\mathrm{NO}_{2} \mathrm{C}_{6} \mathrm{H}_{4} ; \mathbf{6 f}$ & $4-\mathrm{NO}_{2} \mathrm{C}_{6} \mathrm{H}_{4} ; 9 \mathbf{d}$ & 5 & 91 \\
\hline 7 & $2 \mathbf{a}$ & 2-Indolyl; 6g & 2-Indolyl; 9m & 4.5 & 83 \\
\hline 8 & $2 \mathbf{a}$ & $\mathrm{PhCH}_{2} ; \mathbf{6 h}$ & $\mathrm{PhCH}_{2} ; \mathbf{9 f}$ & 6 & $85^{\mathrm{c}}$ \\
\hline 9 & $2 \mathbf{a}$ & $c-\mathrm{C}_{6} \mathrm{H}_{11} ; \mathbf{6} \mathbf{i}$ & $c-\mathrm{C}_{6} \mathrm{H}_{11} ; 9 \mathrm{~g}$ & 8 & 88 \\
\hline 10 & $2 \mathbf{a}$ & $t-\mathrm{C}_{4} \mathrm{H}_{9} ; \mathbf{6} \mathbf{j}$ & $t-\mathrm{C}_{4} \mathrm{H}_{9} ; 9 \mathbf{h}$ & 24 & 86 \\
\hline 11 & $2 \mathbf{a}$ & $\mathrm{Ph} ; \mathbf{7 a}$ & $\mathrm{Ph} ; \mathbf{1 3 b}$ & 48 & d \\
\hline 12 & $2 \mathbf{a}$ & $\mathrm{Me} ; \mathbf{7 b}$ & $\mathrm{Me} ; \mathbf{1 3 c}$ & 48 & 87 \\
\hline 13 & $2 b$ & $\mathrm{Ph} ; \mathbf{6 a}$ & $\mathrm{Ph} ; \mathbf{1 0 a}$ & 5 & $63^{\mathrm{e}, \mathrm{f}}$ \\
\hline 14 & $2 b$ & $2-\mathrm{MeOC}_{6} \mathrm{H}_{4} ; \mathbf{6 b}$ & $2-\mathrm{MeOC}_{6} \mathrm{H}_{4} ; \mathbf{1 0 b}$ & 7 & $63^{e}$ \\
\hline 15 & $2 b$ & $3-\mathrm{MeOC}_{6} \mathrm{H}_{4} ; \mathbf{6 c}$ & $3-\mathrm{MeOC}_{6} \mathrm{H}_{4} ; \mathbf{1 0 c}$ & 6 & $66^{e}$ \\
\hline 16 & $2 \mathbf{b}$ & $4-\mathrm{MeOC}_{6} \mathrm{H}_{4} ; \mathbf{6 d}$ & $4-\mathrm{MeOC}_{6} \mathrm{H}_{4} ; \mathbf{1 0 d}$ & 4 & $64^{e}$ \\
\hline 18 & $2 b$ & $4-\mathrm{ClC}_{6} \mathrm{H}_{4} ; \mathbf{6 e}$ & $4-\mathrm{ClC}_{6} \mathrm{H}_{4} ; \mathbf{1 0 e}$ & 6 & $60^{e}$ \\
\hline 19 & $2 b$ & $4-\mathrm{NO}_{2} \mathrm{C}_{6} \mathrm{H}_{4} ; \mathbf{6 f}$ & $4-\mathrm{NO}_{2} \mathrm{C}_{6} \mathrm{H}_{4} ; \mathbf{1 0 f}$ & 12 & $47^{\mathrm{e}}$ \\
\hline 20 & $2 b$ & $\mathrm{PhCH}_{2} ; \mathbf{6 h}$ & $\mathrm{PhCH}_{2} ; \mathbf{1 0 g}$ & 12 & - \\
\hline 21 & $2 \mathbf{b}$ & $\mathrm{Me} ; \mathbf{7 b}$ & Me; 20b & 48 & $55^{\mathrm{g}}$ \\
\hline 22 & $2 c$ & $\mathrm{Ph} ; \mathbf{6 a}$ & $\mathrm{Ph} ; \mathbf{1 1 a}$ & 2 & $\mathrm{~h}$ \\
\hline
\end{tabular}

${ }^{a}$ Yields refer to the pure products. ${ }^{b}$ Reactants were in equimolar amounts $(10 \mathrm{mmol})$. The reactions were carried out in neat conditions at $50{ }^{\circ} \mathrm{C}$ and in the presence of 5 mol- $\%$ of 1. ${ }^{\mathrm{c}}$ Without $\mathbf{1}$, the reaction time was considearbly longer $(48 \mathrm{~h})$ and the yield lower $(61 \%) .{ }^{\mathrm{d}}$ Only traces of 13b were detected on GC-MS analyses, MS, $m / z(\%)=227(45)\left[\mathrm{M}^{+}\right], 212(80), 150$ (100). ${ }^{\mathrm{e}}$ Reactants were in equimolar amounts $(10 \mathrm{mmol})$. The reactions were carried out in neat conditions at $120{ }^{\circ} \mathrm{C}$ and in the presence of 5 mol- $\%$ of $1 .{ }^{\mathrm{f}}$ At $50{ }^{\circ} \mathrm{C}$ the sole product was imine 
19a. ${ }^{\mathrm{g}}$ Product 20b was purified by flash column chromatography on silica gel $\left(\mathrm{CH}_{2} \mathrm{Cl}_{2}\right)$. ${ }^{\mathrm{h}}$ The sole product of the reaction was $N, N$-dibenzylidene- $o$-phenylenediamine $(\mathbf{2 2 a}), \mathrm{MS}, \mathrm{m} / \mathrm{z}(\%)=$ 284 (100) $\left[\mathrm{M}^{+}\right], 91(80)$.

The use of aldehydes 6 is particularly interesting: $\mathrm{H}_{2} \mathrm{O}$ is the only by-product and the oxidation of the intermediate benzothiazolines $\mathbf{1 3}$ takes place easily with air.

The next reaction to be examined was the reaction of $\mathbf{2 b}$ with $\mathbf{4 a}$ or $\mathbf{8 a}$ in the presence of 5 mol-\% of 1 as a catalyst, in order to obtain benzoxazole 10a. Using the same conditions as described previously for the synthesis of 9a, the only useful positive results occurred with $8 \mathbf{a}$ (Table 1, entry 6). In fact, 10a was easily obtained in good yields (93\%). When using $\mathbf{4 a}$, the GC-MS analyses of the reaction mixture showed the presence of amide $\mathbf{1 7} \mathbf{a}$ as the major product and only traces of 10a (Scheme 4; Table 1, entry 5). The same result was also obtained when both the reaction temperature and the amount of catalyst $\left(80^{\circ} \mathrm{C}\right.$ and 10 mol-\% respectively; Table 1, entry 5) were increased. Indeed, under these conditions even the product of diacylation 18a formed. Evidently, the more weakly nucleophilic $\mathrm{OH}$ group was not able to promote the cyclization reaction (Scheme 4).

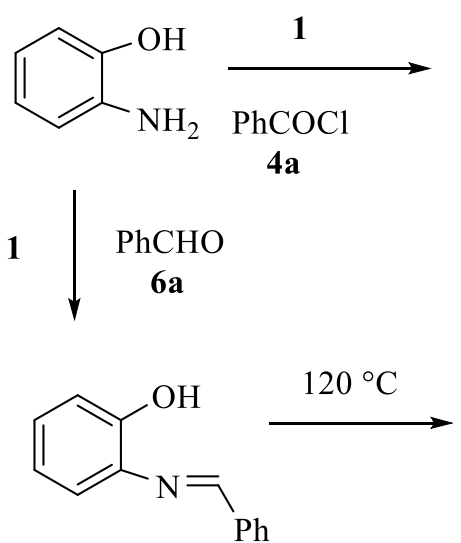

19a



17a: $\mathrm{X}=\mathrm{H}$ and 18a: $\mathrm{X}=\mathrm{COPh}$

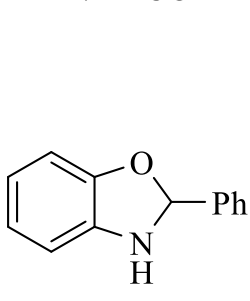<smiles>c1ccc(-c2nc3ccccc3o2)cc1</smiles>

$10 \mathbf{a}$ 20a

Scheme 4. Reaction between $\mathbf{2 b}$ and $\mathbf{4 a}$ or $\mathbf{6 a}$.

In the light of this information, the reaction between $\mathbf{2 b}, \mathbf{2 e}$ and $\mathbf{2 f}$ and selected orthoesters 8a-f furnished the corresponding benzoxazoles $\mathbf{1 0}$ in excellent yields (Scheme 2; 10 examples. Table 6, entries 1-10. Average yield 89\%). The reaction conditions were very simple, mild, efficient and the work-up was very easy and convenient also in this case.1 was easily recovered in all the reactions.

On the other hand, reacting $\mathbf{6 a}$ with $\mathbf{2 b}$ in the presence of 5 mol- $\%$ of $\mathbf{1}$ at $50{ }^{\circ} \mathrm{C}$, the GC-MS and ${ }^{1} \mathrm{H}-\mathrm{NMR}$ (singlet at $8.40 \mathrm{ppm}$ among other peaks) showed the presence of imine 19a as the only product. No traces of possible benzoxazoline 20a and target product 10a were detected (Scheme 4; Table 5, entry 13).However, at $120{ }^{\circ} \mathrm{C}$ the oxidative cyclization occurred and 10a 
was obtained with a fairly good yield (61\%; Scheme 3; Table 5, entry 13$)$. So, it was possible to obtain benzoxazoles $\mathbf{1 0}$ in moderate yield by heating at $120{ }^{\circ} \mathrm{C} \mathbf{2 b}$ and aromatic aldehydes $\mathbf{6 b}-\mathbf{f}$ (6 examples. Table 5, entries 14-19. Average yields 60\%). Only tars formed when using aliphatic aldehydes (Table 5, entry 20). Benzoxazoline 20b was also obtained in moderate yield (Table 5, entry 21).

Table 6. Reactions between $2 \mathrm{~b}, \mathbf{2 e}, \mathbf{2 f}$ and 8

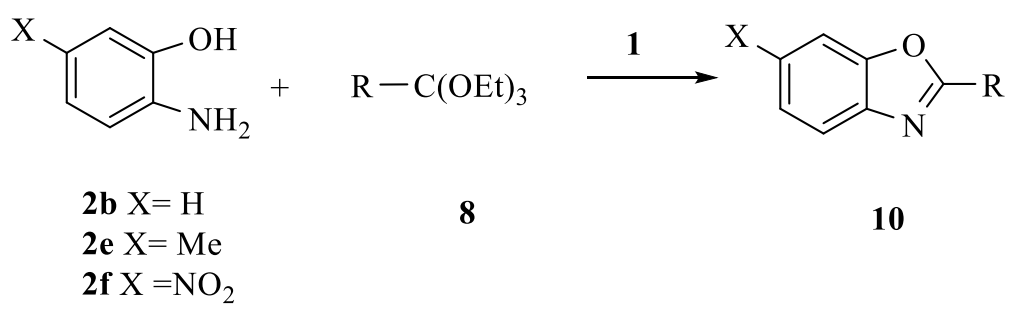

\begin{tabular}{ccccc}
\hline Entry & $\mathrm{R} ;$ reactant $\mathbf{8}$ & $\mathrm{R} ;$ product $\mathbf{1 0}$ & Time $(\mathrm{h})$ & Yield $(\%)^{\mathrm{a}, \mathrm{b}}$ \\
\hline 1 & $\mathrm{Ph} ; \mathbf{8 a}$ & $\mathrm{Ph} ; \mathbf{1 0 a}$ & 2 & 93 \\
2 & $4-\mathrm{MeOC}_{6} \mathrm{H}_{4} ; \mathbf{8 b}$ & $4-\mathrm{MeOC}_{6} \mathrm{H}_{4} ; \mathbf{1 0 d}$ & 3 & 90 \\
3 & $4-\mathrm{ClC}_{6} \mathrm{H}_{4} ; \mathbf{8 c}$ & $4-\mathrm{ClC}_{6} \mathrm{H}_{4} ; \mathbf{1 0 e}$ & 3 & 87 \\
4 & $4-\mathrm{NO}_{2} \mathrm{C}_{6} \mathrm{H}_{4} ; \mathbf{8 d}$ & $4-\mathrm{NO}_{2} \mathrm{C}_{6} \mathrm{H}_{4} ; \mathbf{1 0 f}$ & 4 & 90 \\
5 & $\mathrm{Me} ; \mathbf{8 e}$ & $\mathrm{Me} ; \mathbf{1 0 g}$ & 3 & 93 \\
6 & $\mathrm{PhCH}_{2} ; \mathbf{8 f}$ & $\mathrm{PhCH}_{2} ; \mathbf{1 0 h}$ & 3 & 85 \\
7 & $\mathrm{Ph} ; \mathbf{8 a}^{\mathrm{c}}$ & $\mathrm{Ph} ; \mathbf{1 0 i}(\mathrm{X}=\mathrm{Me})$ & 3 & 91 \\
8 & $\mathrm{Me} ; \mathbf{8} \mathbf{e}^{\mathrm{c}}$ & $\mathrm{Me} ; \mathbf{1 0 j}(\mathrm{X}=\mathrm{Me})$ & 3 & 84 \\
9 & $\mathrm{Ph} ; \mathbf{8 a}^{\mathrm{d}}$ & $\mathrm{Ph} ; \mathbf{1 0 k}\left(\mathrm{X}=\mathrm{NO}_{2}\right)$ & 4 & 87 \\
10 & $\mathrm{Me} ; \mathbf{8 e ^ { \mathrm { d } }}$ & $\mathrm{Me} ; \mathbf{1 0 1}\left(\mathrm{X}=\mathrm{NO}_{2}\right)$ & 4 & 85 \\
\hline
\end{tabular}

${ }^{a}$ Yields refer to the pure products. ${ }^{b}$ Reactants were in equimolar amounts $(10 \mathrm{mmol})$. The reactions were carried out in neat conditions at r.t. and in the presence of 5 mol-\% of $1 .{ }^{c}$ The other reactant was $\mathbf{2 e}{ }^{\mathrm{d}}$ The other reactant was $\mathbf{2 f}$.

Finally, we studied the reaction between $\mathbf{2 c}$ and 4a, 5a, 8a (Table 1, entries 7-9), 6a (Table 5 , entry 22) in the presence of 5 mol-\% of $\mathbf{1}$ as a catalyst in order to obtain benzimidazoles $\mathbf{5}$. First of all, due to the formation of $\mathrm{HCl}$ and the subsequent protonation of the $\mathrm{NH}_{2}$ group, the reaction between $\mathbf{2 c}$ and $\mathbf{4 a}$ only allowed the formation of product $\mathbf{2 1 a}$ (Scheme 5; Table 1, entry 7). Furthermore, the reaction with $\mathbf{6 a}$ does not give positive results: in fact only adduct $\mathbf{2 2 a}$ was recovered (Scheme 5; Table 5, entry 22).

On the other hand, both $5 \mathbf{a}$ and $8 \mathbf{a}$ proved to be excellent reagents for the synthesis of benzimidazoles, in the presence of 5 mol-\% of $\mathbf{1}$ as a catalyst. Therefore, the reaction between 2c, 2e and $\mathbf{2 f}$ with selected 5 (8 examples. Table 7, entries 1-8. Average yield, 77\%) and 8 (10 examples. Table 7, entries 9-18. Average yield, 91\%) furnished the corresponding benzimid- 
azoles $\mathbf{1 1}$ in very good yields. The reaction conditions were always very simple and efficient and 1 was easily recovered (Scheme 2).<smiles>Nc1ccccc1NC(=O)c1ccccc1</smiles>

21a

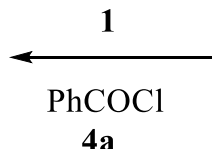

4a<smiles>Nc1ccccc1N</smiles>

2c

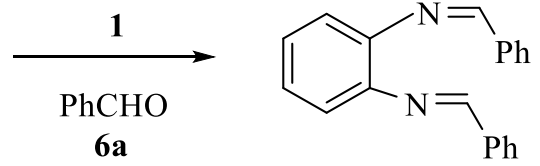

22a

Scheme 5. Reaction between $2 \mathbf{c}$ and $4 \mathbf{a}$ or $6 \mathbf{a}$.

Table 7. Reactions between $2 \mathrm{c}, 2 \mathrm{~g}, 2 \mathrm{~h}$ and 5 or $\mathbf{8}$<smiles>[X]c1ccc(N)c(N)c1</smiles>

2c $\mathrm{X}=\mathrm{H}$ 2g X=Me 2h $\mathrm{X}=\mathrm{NO}_{2}$<smiles>[R]C(=O)OC([R])=O</smiles>
5<smiles>[R]C(=O)OCC(C)C</smiles><smiles>[X]c1ccc2nc([R])[nH]c2c1</smiles>

8
11

\begin{tabular}{|c|c|c|c|c|}
\hline Entry & R; reactant 5 or 8 & $\mathrm{R}$; product $\mathbf{1 1}$ & Time (h) & Yield $(\%)^{\mathrm{a}}$ \\
\hline 1 & $\mathrm{Ph} ; \mathbf{5 a}$ & $\mathrm{Ph} ; 11 \mathrm{a}$ & 6 & $87^{b}$ \\
\hline 2 & $4-\mathrm{MeOC}_{6} \mathrm{H}_{4} ; \mathbf{5 b}$ & $4-\mathrm{MeOC}_{6} \mathrm{H}_{4} ; \mathbf{1 1 b}$ & 8 & $85^{\mathrm{c}}$ \\
\hline 3 & $4-\mathrm{ClC}_{6} \mathrm{H}_{4} ; \mathbf{5 c}$ & $4-\mathrm{ClC}_{6} \mathrm{H}_{4} ; 11 \mathrm{c}$ & 6.5 & $86^{\mathrm{c}}$ \\
\hline 4 & $4-\mathrm{NO}_{2} \mathrm{C}_{6} \mathrm{H}_{4} ; \mathbf{5 d}$ & $4-\mathrm{NO}_{2} \mathrm{C}_{6} \mathrm{H}_{4} ; \mathbf{1 1 d}$ & 9 & $87^{\mathrm{c}}$ \\
\hline 5 & $\mathrm{Me} ; \mathbf{5 e}$ & Me; 11e & 12 & $84^{\mathrm{b}}$ \\
\hline 6 & $\mathrm{PhCH}_{2} ; \mathbf{5 f}$ & $\mathrm{PhCH}_{2} ; \mathbf{1 1 f}$ & 15 & $74^{\mathrm{b}}$ \\
\hline 7 & $c-\mathrm{C}_{6} \mathrm{H}_{11} ; \mathbf{5 g}$ & $c-\mathrm{C}_{6} \mathrm{H}_{11} ; 11 \mathrm{~g}$ & 18 & $54^{\mathrm{b}}$ \\
\hline 8 & $t-\mathrm{C}_{4} \mathrm{H}_{9} ; \mathbf{5} \mathbf{h}$ & $t-\mathrm{C}_{4} \mathrm{H}_{9} ; \mathbf{1 1 h}$ & 24 & $63^{\mathrm{b}}$ \\
\hline 9 & $\mathrm{Ph} ; \mathbf{8 a}$ & $\mathrm{Ph} ; \mathbf{1 1 a}$ & 3 & $92^{\mathrm{d}}$ \\
\hline 10 & $4-\mathrm{MeOC}_{6} \mathrm{H}_{4} ; \mathbf{8 b}$ & $4-\mathrm{MeOC}_{6} \mathrm{H}_{4} ; \mathbf{1 1 b}$ & 3.5 & $90^{\mathrm{d}}$ \\
\hline 11 & $4-\mathrm{ClC}_{6} \mathrm{H}_{4} ; \mathbf{8 c}$ & $4-\mathrm{ClC}_{6} \mathrm{H}_{4} ; \mathbf{1 1 c}$ & 4 & $91^{\mathrm{d}}$ \\
\hline 12 & $4-\mathrm{NO}_{2} \mathrm{C}_{6} \mathrm{H}_{4} ; \mathbf{8 d}$ & $4-\mathrm{NO}_{2} \mathrm{C}_{6} \mathrm{H}_{4} ; \mathbf{1 1 d}$ & 5 & $92^{\mathrm{d}}$ \\
\hline 13 & $\mathrm{Me} ; \mathbf{8 e}$ & Me; 11e & 4.5 & $95^{\mathrm{d}}$ \\
\hline 14 & $\mathrm{PhCH}_{2} ; \mathbf{8 f}$ & $\mathrm{PhCH}_{2} ; \mathbf{1 1 f}$ & 4 & $91^{\mathrm{d}}$ \\
\hline 15 & $\mathrm{Ph} ; \mathbf{8 a}^{\mathrm{e}}$ & $\mathrm{Ph} ; \mathbf{1 1 i}(\mathrm{X}=\mathrm{Me})$ & 3.5 & $92^{\mathrm{d}}$ \\
\hline 16 & $\mathrm{Me} ; \mathbf{8 e}^{\mathrm{e}}$ & $\mathrm{Me} ; \mathbf{1 1} \mathbf{j}(\mathrm{X}=\mathrm{Me})$ & 4 & $89^{d}$ \\
\hline 17 & $\mathrm{Ph} ; \mathbf{8 a}^{\mathrm{f}}$ & $\mathrm{Ph} ; \mathbf{1 1 k}\left(\mathrm{X}=\mathrm{NO}_{2}\right)$ & 6 & $88^{\mathrm{d}}$ \\
\hline 18 & $\mathrm{Me} ; \mathbf{8 e}^{\mathrm{f}}$ & $\mathrm{Me} ; 11 \mathrm{I}\left(\mathrm{X}=\mathrm{NO}_{2}\right)$ & 5.5 & $90^{\mathrm{d}}$ \\
\hline
\end{tabular}

${ }^{a}$ Yields refer to the pure products. ${ }^{b}$ Reactants were in equimolar amounts $(10 \mathrm{mmol})$. The reactions were carried out in neat conditions at $50{ }^{\circ} \mathrm{C}$ and in the presence of 5 mol- $\%$ of $1 .{ }^{c}$ Due 
to the high mp of $\mathbf{5 b}-\mathbf{d}$, the reaction were carried out in THF at reflux. Lower yields of products 11 were obtained when the same reaction was performed in neat conditions at higher temperature $\left(100{ }^{\circ} \mathrm{C}\right) .{ }^{\mathrm{d}}$ Reactants were in equimolar amounts $(10 \mathrm{mmol})$ in neat conditions. The reactions were carried out in neat conditions at r.t and in the presence of 5 mol- $\%$ of 1 . ${ }^{\text {e }}$ The other reactant was $\mathbf{2 e} .{ }^{\mathrm{f}}$ The other reactant was $\mathbf{2 h}$

\section{Conclusions}

The Brønsted acid (1)-catalyzed synthesis of benzo derivatives of azoles 9, 10 and 11, an efficient, mild and simple procedure, is proposed in this paper. We tested various carboxylic acid derivatives and aldehydes as reactant. Undoubtedly the orthoesters $\mathbf{8}$ are by far the best; in fact, only they gave all three target products $9, \mathbf{1 0}, 11$ in easy processes.

The reactions were carried out at r.t., under neat conditions (with the sole exception of oily products. In order to isolate them, a solvent extraction was necessary) and the safe by-product EtOH was easily removed. The high yields obtained are comparable to that reported in the literature. ${ }^{12,14 \mathrm{a}, 14 \mathrm{f}}$

Moreover, acid catalyst $\mathbf{1}$ is a safe, non-volatile, non-corrosive Brønsted acid; it was easily recovered at the end of the reactions simply evaporating aqueous washings and it was reused in another four consecutive runs without a significant decrease in catalytic activity. But since only a few of $\mathbf{8}$ are commercially available, alternatively we employed easily available aldehydes $\mathbf{6}$ and acyl chlorides $\mathbf{4}$ to synthesize benzothiazoles $\mathbf{9}$ and anhydrides $\mathbf{5}$ to synthesize benzimidazoles 11.

\section{Experimental Section}

General. All the reactions were conducted in open-air flasks. Analytical grade reagents and solvents were used and reactions were monitored by GC, and GC-MS. Petroleum ether (PE) refers to the fraction boiling in the range $40-70{ }^{\circ} \mathrm{C} .{ }^{1} \mathrm{H} \mathrm{NMR}$ and ${ }^{13} \mathrm{C} \mathrm{NMR}$ were recorded on a Brucker Avance 200 spectrometer at 200 and $50 \mathrm{MHz}$ respectively. Mass spectra were recorded on an HP 5989B mass selective detector connected to an HP 5890 GC. Room temperature (r.t.) is 20-25 ${ }^{\circ} \mathrm{C}$. Melting points were measured on a Stuart Scientific SMP3 apparatus. $o$-Benzenedisulfonimide (1) was prepared as reported. ${ }^{15 f}$ (Now $\mathbf{1}$ is commercially available from 3B Scientific Corporation.) Ortho esters $\mathbf{8 b - d , ~} \mathbf{f}$ were prepared using the Pinner synthesis. ${ }^{16}$ Anhydrides 5b, 5d, 5f, 5g were prepared by reacting the appropriate acyl chloride with the corresponding sodium salt of the carboxylic acid or reacting the acyl chloride with the corresponding carboxylic acid in the presence of pyridine. All the other reactants were purchased from Sigma-Aldrich or from Alpha-Aesar. Yields of the pure (GC, MS, ${ }^{1} \mathrm{H}$ NMR, ${ }^{13} \mathrm{C}$ NMR) isolated products $\mathbf{9}, \mathbf{1 0}$ and $\mathbf{1 1}$ are reported in Tables 2, 5, 6, 7. Structures and purity of the 
products 9, 10, 11 were confirmed by comparison of their physical and spectral data with those reported in the literature. The physical and spectral data of the obtained products in most cases are in accordance with those reported in the literature. The spectral data of the products $\mathbf{9 , 1 0 , 1 1}$ are reported in the Supplementary Material.

2-Phenylbenzothiazole (9a). Typical procedure for the preparation of benzothiazoles 9 from orthoesters 8 or acyl chlorides 4 . In entry 8 (Table 2) $o$-benzenedisulfonimide (1; 5 $\mathrm{mol} \% ; 110 \mathrm{mg}, 0.5 \mathrm{mmol}$ ) was added to a mixture of 2-aminothiophenol (2a, $1.25 \mathrm{~g}, 10 \mathrm{mmol})$ and triethyl orthobenzoate $(8 \mathrm{a}, 2.24 \mathrm{~g}, 10 \mathrm{mmol})$. The mixture was stirred at r.t. The reaction was monitored by GC and GC-MS until the complete disappearance of starting products (1.5 h). Cold water $(20 \mathrm{ml})$ was added to the reaction mixture, under vigorous stirring. The resulting solid was filtered on a Büchner funnel and washed with additional cold water $(2 \times 5 \mathrm{ml})$ and small amount of PE (5 ml). It was virtually pure (GC, MS, $\left.{ }^{1} \mathrm{H} \mathrm{NMR},{ }^{13} \mathrm{C} \mathrm{NMR}\right)$ title compound 9a, a pale yellow solid; yield: $90 \%$ (1.90 g). The oily benzothiazoles $\mathbf{9 e}-\mathbf{h}$ were recovered extracting with EtOAc the crude residue.

The aqueous washings were collected and evaporated under reduced pressure. After the removal of $\mathrm{H}_{2} \mathrm{O}$, virtually pure $\left({ }^{1} \mathrm{H} \mathrm{NMR}\right) o$-benzenedisulfonimide (1) was recovered $(100 \mathrm{mg}, 91 \%$ yield). The recovered $\mathbf{1}$ was employed in another four catalytic cycles under the conditions described above, reacting with $\mathbf{2 a}$ and $\mathbf{8 a}$; Table 3 reported the yields of $\mathbf{9 a}$ and the yields of recovered 1. Spectral data on the products are presented as Supplementary Data.

2-Phenylbenzothiazole (9a). Typical procedure for the preparation of benzothiazoles 9 from aldehydes 6. In entry 1 (Table 5) a mixture of 2-aminothiophenol (2a, $1.25 \mathrm{~g}, 10 \mathrm{mmol}$ ) and benzaldehyde (6a, $1.06 \mathrm{~g}, 10 \mathrm{mmol})$ was stirred at $50{ }^{\circ} \mathrm{C}$. After 1 hour, GC and GC-MS analyses showed the presence of two peaks: the first was 9a, MS, $m / z(\%)=211(100)\left[\mathrm{M}^{+}\right], 108$ (25) and the second may have been 12a or 13a, MS, $m / z(\%)=213(70)\left[\mathrm{M}^{+}\right], 212(100), 136$ (50). However, the ${ }^{1} \mathrm{H}-\mathrm{NMR}\left(200 \mathrm{MHz}, \mathrm{CDCl}_{3}\right.$ ) analyses most probably showed the presence of both. In fact, among others, two distinct singlets were clearly visible, the first $\left(\delta_{\mathrm{H}} 6.36, \mathrm{H}-2\right)$ due to $13 \mathbf{a}$; the second $\left(\delta_{\mathrm{H}} 8.51, \underline{\mathrm{HC}}=\mathrm{N}\right)$ due to $\mathbf{1 2 a}$. At this point, $o$-benzenedisulfonimide $(\mathbf{1} ; 5 \mathrm{~mol}-$ $\% ; 110 \mathrm{mg}, 0.5 \mathrm{mmol}$ ) was added to the reaction mixture. After 3 hours, the intermediates 12a and 13a disappeared. Cold $\mathrm{H}_{2} \mathrm{O}(20 \mathrm{ml})$ was added to the reaction mixture, under vigorous stirring. The resulting solid was filtered on a Büchner funnel and washed with additional cold water $(2 \times 5 \mathrm{ml})$ and small amount of PE $(5 \mathrm{ml})$. It was the virtually pure $\left(\mathrm{GC}, \mathrm{MS},{ }^{1} \mathrm{H} \mathrm{NMR},{ }^{13} \mathrm{C}\right.$ NMR) title compound 9a, a pale yellow solid; yield: $88 \%(1.85 \mathrm{~g})$. The aqueous washings were collected and evaporated under reduced pressure. After the removal of $\mathrm{H}_{2} \mathrm{O}$, virtually pure $\left({ }^{1} \mathrm{H}\right.$ NMR) o-benzenedisulfonimide (1) was recovered (91 $\mathrm{mg}, 83 \%$ yield). The reaction also completed without adding 1 . However, the reaction time was longer (36 h) and the yield lower (73\%; $1.54 \mathrm{~g})$. On the other hand, adding $\mathbf{1}$ to a mixture of $\mathbf{2 a}$ and $\mathbf{1 1 a}$ from the beginning of the reaction, after $1 \mathrm{~h}$ GC and GC-MS showed three peaks: 9a, 12a or 13a and adduct 16a, MS, $\mathrm{m} / \mathrm{z}$ $=303(85)\left[\mathrm{M}^{+}\right], 226(75), 212(90), 91$ (100). Continuing the stirring at $50{ }^{\circ} \mathrm{C}$, after 3 h only $9 \mathbf{a}$ and $16 \mathbf{a}$ were detected. 
2-Phenylbenzothiazole (9a). Pale yellow solid; mp 116-117 ${ }^{\circ} \mathrm{C}\left(\mathrm{EtOH} ;\right.$ lit. $\left.^{17} 115-116{ }^{\circ} \mathrm{C}\right)$. Yield: $90 \%$ (1.90 g) from 2a and 8a; 87\% (1.84g) from 2a and 4a; 88\% (1.87g) from 2a and 6a. 2-(4-Methoxyphenyl)benzothiazole (9b). Pale yellow solid; mp 126-127 ${ }^{\circ} \mathrm{C}$ (EtOH; lit. ${ }^{18} 127-$ $128{ }^{\circ} \mathrm{C}$ ). Yield: $90 \%$ (2.18 g) from $\mathbf{2 a}$ and $\mathbf{8 b} ; 83 \%(2.00 \mathrm{~g})$ from $\mathbf{2 a}$ and $\mathbf{4 b} ; 87 \%$ (2.10 g) from 2a and 6d.

2-(4-Chlorophenyl)benzothiazole (9c). Pale yellow solid; mp 116-117 ${ }^{\circ} \mathrm{C}$ (EtOH; lit. ${ }^{19} 111.5-$ $\left.112.5{ }^{\circ} \mathrm{C}\right)$. Yield: $92 \%$ (2.27 g) from $\mathbf{2 a}$ and $\mathbf{8 c}$; $80 \%$ (1.95 g) from $\mathbf{2 a}$ and $\mathbf{4 c} ; 90 \%$ (2.21 g) from $2 \mathbf{a}$ and $6 \mathbf{e}$.

2-(4-Nitrophenyl)benzothiazole (9d). Yellow solid; mp 224-226 ${ }^{\circ} \mathrm{C}\left(\mathrm{EtOH} ;\right.$ lit. $\left.^{20} 226-228{ }^{\circ} \mathrm{C}\right)$. Yield: $91 \%$ (2.34 g) from 2a and 8d; 76\% (1.95 g) from 2a and 4d; $91 \%$ (2.34 g) from $\mathbf{2 a}$ and $\mathbf{6 f}$. 2-Methylbenzothiazole (9e).Pale yellow oil. ${ }^{21}$ Yield: $90 \%$ (1.34 g) from $\mathbf{2 a}$ and 8e; $81 \%$ (1.19 g) from $2 \mathbf{a}$ and $\mathbf{4 e}$.

2-Benzylbenzothiazole (9f). Pale yellow oil. ${ }^{22}$ Yield: $90 \%$ (2.02 g) from 2a and 8f; 85\% (1.91 g) from $2 \mathbf{a}$ and $\mathbf{6 h}$.

2-Cyclohexylbenzothiazole (9g). Pale yellow oil. ${ }^{23}$ Yield: 53\% (1.15 g) from 2a and 4f; $88 \%$ $(1.92 \mathrm{~g})$ from $2 \mathbf{a}$ and $\mathbf{6 i}$.

2-t-Butylbenzothiazole (9h). Pale yellow oil. ${ }^{24}$ Yield: $42 \%(0.80 \mathrm{~g})$ from $\mathbf{2 a}$ and $\mathbf{4 g}$; $86 \%$ (1.66 g) from $2 \mathbf{a}$ and $\mathbf{6 j}$.

5-Chloro-2-phenylbenzothiazole (9i).Pale brown solid; mp 136-138 ${ }^{\circ} \mathrm{C}$ (EtOH; lit. ${ }^{25} 138-139$ $\left.{ }^{\circ} \mathrm{C}\right)$. Yield: $90 \%$ (2.21 g) from $\mathbf{2 d}$ and $\mathbf{8 a}$.

5-Chloro-2-methylbenzothiazole (9j).Pale brown solid; mp 66-68 ${ }^{\circ} \mathrm{C}\left(\mathrm{EtOH} ;\right.$ lit. $\left.^{26} 68-69{ }^{\circ} \mathrm{C}\right)$. Yield: $86 \%$ (1.57 g) from $2 \mathbf{d}$ and $8 \mathbf{e}$.

2-(2-Methoxyphenyl)benzothiazole (9k).Pale yellow solid; mp104-105 ${ }^{\circ} \mathrm{C}$ (EtOH; lit. ${ }^{27} 95-98$ $\left.{ }^{\circ} \mathrm{C}\right)$. Yield: $84 \%$ (2.04 g) from $\mathbf{2 a}$ and $\mathbf{6 b}$.

2-(3-Methoxyphenyl)benzothiazole (9l).Pale yellow solid; mp 80-81 ${ }^{\circ} \mathrm{C}$ (EtOH; lit. ${ }^{19} 81.5-82$ $\left.{ }^{\circ} \mathrm{C}\right)$. Yield: $84 \%$ (2.04 g) from $\mathbf{2 a}$ and $\mathbf{6 c}$.

2-(2-Indolyl)benzothiazole (9m).Brown solid; mp168-170 ${ }^{\circ} \mathrm{C}\left(\mathrm{EtOH} ;\right.$ lit. $\left.^{28} 144-146{ }^{\circ} \mathrm{C}\right)$. Yield: $83 \%(2.06 \mathrm{~g})$ from $\mathbf{2 a}$ and $\mathbf{6 g}$.

2,2-Dimethylbenzothiazoline (13c). Waxy grey solid (mp lit. $\left.{ }^{29} 44-45{ }^{\circ} \mathrm{C}\right)$. Yield: $87 \%(1.44 \mathrm{~g})$ from $2 \mathbf{a}$ and $7 \mathbf{b}$.

2-Phenylbenzoxazole (10a). Typical procedure for the preparation of benzoxazoles from aldehydes 6. According to the procedure described above, in entry 13 (Table 5) $o$ benzenedisulfonimide $(1 ; 5 \mathrm{~mol}-\% ; 110 \mathrm{mg}, 0.5 \mathrm{mmol})$ was added to a mixture of 2aminophenol (2b, $1.09 \mathrm{~g}, 10 \mathrm{mmol})$ and benzaldehyde (6a, $1.06 \mathrm{~g}, 10 \mathrm{mmol})$. The mixture was stirred at $50{ }^{\circ} \mathrm{C}$. After 24 hour, GC, MS and ${ }^{1} \mathrm{H}$ NMR analyses showed the presence of the immine 19a. ${ }^{1} \mathrm{H}$ NMR $\left(200 \mathrm{MHz}, \mathrm{CDCl}_{3}\right): \delta_{\mathrm{H}} 8.64(\mathrm{~s}, 1 \mathrm{H}, \underline{\mathrm{HC}}=\mathrm{N}), 7.89-7.85(\mathrm{~m}, 2 \mathrm{H}), 7.45-7.45$ (m, 3H), 7.28-7.11 (m, 2H), 6.99-6.85 (m, 2H), 4.84 (br s, 1H); MS, $m / z(\%)=197(100)\left[\mathrm{M}^{+}\right]$, 196 (100), 120 (100). On the other hand, heating at $120^{\circ} \mathrm{C}$ for 5 hours we obtained the title compound 10a in fairly good yield $(1.22 \mathrm{~g} ; 63 \%)$. 
2-Phenylbenzoxazole (10a). Grey solid; mp 103-104 ${ }^{\circ} \mathrm{C}\left(\mathrm{EtOH} ;\right.$ lit. $\left.^{30} 102-103{ }^{\circ} \mathrm{C}\right)$. Yield: $93 \%$ $(1.82 \mathrm{~g})$ from $\mathbf{2 b}$ and $\mathbf{8 a} ; 63 \%$ (1.22 g) from $\mathbf{2 b}$ and $\mathbf{6 a}$.

2-(2-Methoxyphenyl)benzoxazole (10b). Pale yellow solid; mp 56-57 ${ }^{\circ} \mathrm{C}$ (EtOH; lit. $^{31}$ 53-55 $\left.{ }^{\circ} \mathrm{C}\right)$. Yield: $63 \%$ (1.42 g) from $\mathbf{2 b}$ and $\mathbf{6 b}$.

2-(3-Methoxyphenyl)benzoxazole (10c). Pale yellow solid; mp 73-74 ${ }^{\circ} \mathrm{C}$ (EtOH; lit. ${ }^{31} 71.3-$ $\left.73.8^{\circ} \mathrm{C}\right)$. Yield: $66 \%(1.48 \mathrm{~g})$ from $\mathbf{2 b}$ and $\mathbf{6 c}$.

2-(4-Methoxyphenyl)benzoxazole (10d). Pale yellow solid; mp 103-104 ${ }^{\circ} \mathrm{C}$ (EtOH; lit. ${ }^{32} 100-$ $\left.102{ }^{\circ} \mathrm{C}\right)$. Yield: $90 \%(2.02 \mathrm{~g}$ ) from $\mathbf{2 b}$ and $\mathbf{8 b} ; 64 \%(1.44 \mathrm{~g})$ from $\mathbf{2 b}$ and $\mathbf{6 d}$.

2-(4-Chlorophenyl)benzoxazole (10e). Pale yellow solid; mp $153-154{ }^{\circ} \mathrm{C}$ (EtOH; lit. ${ }^{32}$ 150-152 $\left.{ }^{\circ} \mathrm{C}\right)$. Yield: $87 \%(2.00 \mathrm{~g}$ ) from $\mathbf{2 b}$ and $\mathbf{8 c}$; $60 \%$ (1.37 g) from $\mathbf{2 b}$ and $\mathbf{6 e}$.

2-(4-Nitrophenyl)benzoxazole (10f). Yellow solid; mp 271-273 ${ }^{\circ} \mathrm{C}$ (EtOH; lit. ${ }^{32} 270-272$ ${ }^{\circ}$ C).Yield: $90 \%$ (2.15 g) from $\mathbf{2 b}$ and $\mathbf{8 d}$; $47 \%(1.13 \mathrm{~g})$ from $\mathbf{2 b}$ and $\mathbf{6 f}$.

2-Methylbenzoxazole (10g). Pale yellow oil. ${ }^{33}$ Yield: $93 \%$ (1.24 g) from $\mathbf{2 b}$ and $\mathbf{8 e .}$

2-Benzylbenzoxazole (10h).Pale yellow oil. ${ }^{31}$ Yield: $85 \%$ (1.77 g) from $\mathbf{2 b}$ and $\mathbf{8 f}$.

6-Methyl-2-phenylbenzoxazole (10i). Pale brown solid; mp 104-105 ${ }^{\circ} \mathrm{C}$ (EtOH; lit. ${ }^{33}$ 99-102 $\left.{ }^{\circ} \mathrm{C}\right)$. Yield: $91 \%(1.90 \mathrm{~g})$ from $2 \mathrm{e}$ and $\mathbf{8 a}$.

2,6-Dimethylbenzoxazole $(\mathbf{1 0 j})$. Pale yellow oil. ${ }^{33}$ Yield: $84 \%(1.23 \mathrm{~g})$ from $\mathbf{2 e}$ and $\mathbf{8 e .}$

6-Nitro-2-phenylbenzoxazole (10k). Pale yellow solid; mp 142-143 ${ }^{\circ} \mathrm{C}$ (EtOH; lit. ${ }^{34} 138-142$ ${ }^{\circ}$ C). Yield: $87 \%$ (2.08 g) from $\mathbf{2 f}$ and $\mathbf{8 a}$.

2-Methyl-6-nitrobenzoxazole (101).Pale yellow solid; mp 171-172 ${ }^{\circ} \mathrm{C}$ (EtOH; lit. ${ }^{34} 170-173$ $\left.{ }^{\circ} \mathrm{C}\right)$. Yield: $85 \%$ (1.52 g) from $\mathbf{2 f}$ and $\mathbf{8 e}$.

2,2-Dimethylbenzoxazoline (20b).Pale yellow oil. ${ }^{35}$ Yield: $55 \%(0.82 \mathrm{~g})$ from $\mathbf{2 b}$ and $\mathbf{7 b}$.

2-Phenylbenzimidazole (11a). Typical procedure for the preparation of benzimidazole from orthoesters 8 or anhydrides 5. According to the procedure described above, in entry 8 (Table 7) $o$-benzenedisulfonimide $(1 ; 5 \mathrm{~mol}-\% ; 110 \mathrm{mg}, 0.5 \mathrm{mmol}$ ) was added to a mixture of $o$ phenylenediamine (2c, $1.11 \mathrm{~g}, 10 \mathrm{mmol})$ and triethyl orthobenzoate (10a, $2.24 \mathrm{~g}, 10 \mathrm{mmol})$. The mixture was stirred at r.t. The reaction was monitored by GC and GC-MS until the complete disappearance of starting products $(3 \mathrm{~h})$. With the same work-up as described above, the virtually pure (GC, MS, ${ }^{1} \mathrm{H}$ NMR, ${ }^{13} \mathrm{C}$ NMR) title compound 11a was obtained; pale grey solid; yield: 93\% (1.70 g). The aqueous washings were collected and evaporated under reduced pressure. After the removal of $\mathrm{H}_{2} \mathrm{O}$, virtually pure $\left({ }^{1} \mathrm{H}\right.$ NMR) $o$-benzenedisulfonimide (1) was recovered (90 mg, $82 \%$ yield).

This procedure was also applied, practically unchanged, using the anhydrides (5). However, in order to eliminate the by-product carboxylic acid, the resulting solid was filtered on a Büchner funnel and washed with aqueous $\mathrm{NaOH}(10 \%)(2 \times 5 \mathrm{ml})$ and small amount of PE $(5 \mathrm{ml})$. In this case, in order to recover $\mathbf{1}$, the aqueous layer was passed through a column of Dowex $50 \mathrm{X} 8$ ion exchange resin; elution was with $\mathrm{H}_{2} \mathrm{O}$. After removal of $\mathrm{H}_{2} \mathrm{O}$ virtually pure $\left({ }^{1} \mathrm{H} \mathrm{NMR}\right) o$ benzenedisulfonimide (1) was recovered.

2-Phenylbenzimidazole (11a). Pale brown solid; mp 293-294 ${ }^{\circ} \mathrm{C}$ (EtOH; lit. ${ }^{36}$ 292-294 $\left.{ }^{\circ} \mathrm{C}\right)$.Yield: $92 \%$ (1.79 g) from $2 \mathbf{c}$ and $\mathbf{8 a} ; 87 \%$ (1.68 g) from $2 \mathbf{c}$ and $\mathbf{5 a}$. 
2-(4-Methoxyphenyl)benzimidazole (11b). Pale yellow solid; mp 223-225 ${ }^{\circ} \mathrm{C}$ (EtOH; lit. ${ }^{36}$ 222-225 ${ }^{\circ} \mathrm{C}$ ). Yield: $90 \%$ (2.01 g) from $\mathbf{2 c}$ and $\mathbf{8 b}$; 85\% (1.90 g) from $\mathbf{2 c}$ and $\mathbf{5 b}$.

2-(4-Chlorophenyl)benzimidazole (11c). Pale yellow solid; mp 294-295 ${ }^{\circ} \mathrm{C}$ (EtOH; lit. ${ }^{37} 292-$ $293{ }^{\circ} \mathrm{C}$ ). Yield: $91 \%$ (2.08 g) from $\mathbf{2 c}$ and $8 \mathbf{c}$; $86 \%$ (1.95 g) from $\mathbf{2 c}$ and $\mathbf{5 c}$.

2-(4-Nitrophenyl)benzimidazole (11d).Yellow solid; mp 264-265 ${ }^{\circ} \mathrm{C}$ (EtOH; lit. ${ }^{36} 259-260$ ${ }^{\circ} \mathrm{C}$ ).Yield: $92 \%$ (2.20 g) from $\mathbf{2 c}$ and $\mathbf{8 d}$; 87\% (2.07 g) from $\mathbf{2 c}$ and $\mathbf{5 d .}$

2-Methylbenzimidazole (11e).Pale yellow solid; mp 175-176 ${ }^{\circ} \mathrm{C}\left(\mathrm{EtOH}\right.$; lit. $\left.{ }^{38} 172-174{ }^{\circ} \mathrm{C}\right)$. Yield: 95\% (1.25 g) from $2 \mathbf{c}$ and $8 \mathbf{e}$; 84\% (1.11 g) from $\mathbf{2 c}$ and $\mathbf{5 e .}$

2-Benzylbenzimidazole (11f). Pale yellow solid; mp 179-180 ${ }^{\circ} \mathrm{C}\left(\mathrm{EtOH} ;\right.$ lit. $\left.^{39} 175{ }^{\circ} \mathrm{C}\right)$. Yield: $91 \%(1.90 \mathrm{~g})$ from $\mathbf{2 c}$ and $\mathbf{8 f}$; $74 \%(1.55 \mathrm{~g})$ from $\mathbf{2 c}$ and $\mathbf{5 f}$.

2-Cyclohexylbenzimidazole (11g). Pale yellow solid; mp 280-282 ${ }^{\circ} \mathrm{C}$ (EtOH; lit. ${ }^{25} \mathrm{mp}>265$ $\left.{ }^{\circ} \mathrm{C}\right)$. Yield: $54 \%$ (1.12 g) from 2c and $\mathbf{5 g}$.

2-t-Butylbenzimidazole (11h). Pale yellow solid; mp >300 ${ }^{\circ} \mathrm{C}\left(\mathrm{EtOH} ;\right.$ lit. $\left.^{36} 303-306{ }^{\circ} \mathrm{C}\right)$. Yield: $63 \%(1.11 \mathrm{~g})$ from $\mathbf{2 c}$ and $\mathbf{5 h}$.

5-Methyl-2-phenylbenzimidazole (11i). Pale brown solid; mp 244-246 ${ }^{\circ} \mathrm{C}$ (EtOH; lit. ${ }^{40} 243-$ $245^{\circ} \mathrm{C}$ ). Yield: $92 \%$ (1.91 g) from $2 \mathbf{h}$ and $\mathbf{5 a}$.

2,5-Dimethylbenzimidazole (11j). Pale grey solid; mp 205-206 ${ }^{\circ} \mathrm{C}\left(\mathrm{EtOH} ;\right.$ lit. $\left.^{41} 203-204{ }^{\circ} \mathrm{C}\right)$. Yield: $89 \%$ (1.30 g) from $\mathbf{2 h}$ and $\mathbf{5 e .}$

5-Nitro-2-phenylbenzimidazole (11k). Pale brown solid; mp 212-213 ${ }^{\circ} \mathrm{C}$ (EtOH; lit. ${ }^{40} 208-210$ $\left.{ }^{\circ} \mathrm{C}\right)$. Yield: $88 \%(2.11 \mathrm{~g})$ from $\mathbf{2 g}$ and $\mathbf{5 a}$.

2-Methyl-5-nitrobenzimidazole (11l ).Pale brown solid; mp 216-218 ${ }^{\circ} \mathrm{C}$ (EtOH; lit. ${ }^{38} 218-220$ $\left.{ }^{\circ} \mathrm{C}\right)$. Yield: $90 \%$ (1.59 g) from $\mathbf{2 g}$ and $\mathbf{5 e}$.

\section{Acknowledgements}

This work was supported by the University of Torino.

\section{References}

1. Katritzky, A. R.; Lagowski, J. M. In Comprehensive Heterocyclic Chemistry; Potts, K. T. Ed.; Pergamon: Oxford, 1984; Vol. 5, Chap. 4.01, pp 1-38 and Chap. 4.02, pp 39-110. (b) Potts, K. T. In Comprehensive Heterocyclic Chemistry; Potts, K. T. Editor; Pergamon: Oxford 1984, Vol. 5, Chap. 4.03, pp 111-166. (c) Chen C.; Chen, Y.-J. Tetrahedron Lett. 2004, 45, 113. (d) Evindar, G.; Batey, A. R. J. Org. Chem. 2006, 71, 1802 and references cited therein.

2. (a) Wen, X.; El Bakali, J.; Deprez-Poulain, R.; Deprez, B. Tetrahedron Lett. 2012, 53, 2440 and references cited therein. (b) Chaney, M. O.; Demarco P. V.; Jones, N. D.; Occolowitz, J. L. J. J. Am. Chem. Soc. 1974, 96, 1932. 
3. (a) Porcari A. R.; Devivar R.V.; Kucera, L. S.; Drach, J. C.; Townsend, L. B. J. Med. Chem. 1998, 41, 1252. (b) Song, X.; Vig, B. S.; Lorenzi, P. L.; Drach, J.C.; Townsend, L. B.; Amidon, G. L. J. Med. Chem. 2005, 48, 1274.

4. Yildiz-Oren, I.; Yalcin, I.; Aki-Sener, E.; Ucarturk, N. Eur. J. Med. Chem. 2004, 39, 291.

5. (a) Kumar, D.; Jacob, M. R; Reynolds, M. B.; Kerwin, S. M. Bioorg. Med. Chem. 2002, 10, 3997. (b) Huang, S. T.; Hsei, I. J.; Chen, C. Bioorg. Med. Chem. 2006, 14, 6106.

6. Evans, D. A.; Sacks, C. E.; Kleschick, W. A.; Taber, T. R. J. Am. Chem. Soc. 1979, 101, 6789.

7. Yamato, M. Yakugaku Zasshi 1992, 112, 81.

8. Benazzouz, A.; Boraud, T.; Dubèdat, P., Boireau, A.; Stutzmann, J.-M.; Gross, C. Eur. J. Pharmacol. 1995, 284, 299.

9. Mader, M.; de Dios, A.; Shih, C.; Anderson, B. D. Bioorg. Med. Chem. Lett. 2008, 18, 179.

10. Raghavendra, G. M.; Ramesha, A. B.; Revanna, C. N.; Nandeesh, K. N.; Mantelingu, K.; Rangappa, K. S. Tetrahedron Lett. 2011, 52, 5571.

11. Facchinetti, V.; Reis, R. D.; Gomes, C. R. B.; Vasconcelos, T. R. A. Mini-Rev. Org. Chem. 2012, 9, 44.

12. Liu, J.; Liu, Q.; Xu, W.; Wang, W. Chin. J. Chem. 2011, 29, 1739.

13. Hojati, S. F.; Maleki, B.; Beykzadeh, Z. Monatsh. Chem. 2011, 142, 87.

14. For other examples of papers of the last two years see: (a) Karami, B.; Ghashghaee, V.; Khodabakhshi, S. Catal. Commun. 2012, 20, 71. (b) Zhang, L.-J.; Xia, J.; Zhou Y.-Q.; Wang, H.; Wang, S. W. Synth. Commun. 2012, 42, 328. (c) Eshghi, H.; Rahimizadeh, M.; Shiri, A.; Sedaghat, P. Bull. Korean Chem. Soc. 2012, 33, 515. (d) Deng, H.; Li, Z.; Ke, F.; Zhou, X. Chem. Eur. J. 2012, 18, 4840. (e) Khurana, J. M.; Sneha; Vij, K. Synth. Commun. 2012, 42, 2606. (f) Aridoss, G.; Laali K. K. Eur. J. Org. Chem. 2011, 2827. (f) Maleki, B.; Azarifar, D.; Hojati S. F.;Veisi, H.; Gholizadeh, M.; Salehabadi, H.; Khodaverdian Moghadam, M. J. Heterocyclic Chem. 2011, 48, 449. (g) Riadi, Y.; Mamouni, R.; Azzalou, R.; El Haddad, M.; Routier, S.; Guillaumet, G.; Lazar, S. Tetrahedron Lett. 2011, 52, 3492.

15. (a) Barbero, M.; Bazzi, S.; Cadamuro, S.; Dughera, S. Curr. Org. Chem. 2011, 15, 576. (b) Barbero, M.; Cadamuro, S.; Dughera, S.; Magistris, C.; Venturello, P. Org. Biomol. Chem. 2011, 9, 8393. (c) Barbero, M.; Cadamuro, S.; Ghigo, G.; Dughera, S. Org. Biomol. Chem. 2012, 10, 4058. (d) Barbero, M.; Bazzi, S.; Cadamuro, S.; Dughera, S. Tetrahedron Lett. 2010, 51, 2342. (e) Barbero, M.; Bazzi, S.; Cadamuro, S.; Dughera, S. Tetrahedron Lett. 2010, 51, 6356. (f) Barbero, M.; Crisma, M.; Degani, I.; Fochi, R.; Perracino, P. Synthesis 1998, 1171.

16. (a) Hunter, M. J.; Ludwig, M. L. J. Am. Chem. Soc. 1962, 84, 3491. (b) Brooker, L.G. S.; White, F. L. J. Am. Chem. Soc. 1935, 57, 2480.

17. Osuka, A.; Uno, Y.; Horiuchi, H.; Suzuki, H. Synthesis 1984, 145.

18. Melzig, L.; Metzger, A.; Knöchel, P. Chem. Eur. J. 2011, 17, 2948.

19. Inamoto, K.; Hasegawa, C.; Hiroya, K.; Doi, T. Org. Lett. 2008, 10, 5147.

20. Chakraborti, A. K.; Rudrawar, S.; Kaur, G.; Sharma, L. Synlett 2004, 1533. 
21. Itoh, T.; Mase, T. Org. Lett. 2007, 9, 3687.

22. Mukai, T.; Hirano, K.; Satoh, T.; Miura, M. Org. Lett. 2010, 12, 1360.

23. Wang, Z.; Tang, R.; Xiao, Q. Chin. J. Chem. 2011, 29, 314.

24. Prasad, D. J. C.; Sekar, G. Org. Lett. 2011, 13, 1008.

25. Lim, H.-J.; Myung, D.; Lee, I. Y. C.; Jung, M. H. J. Comb. Chem. 2008, 10, 501.

26. Huang, X.; Tang, J. Tetrahedron 2003, 59, 4851.

27. Organ, M. G.; Hadi, M. A.; Avola, S.; Dubovyk, I.; Hadei, N.; Nasielski, J.; O’Brien, C. J.; Valente C. Chem. Eur. J. 2007, 13, 150.

28. Qin, X.; Cong, X.; Zhao, D.; You, J.; Lan, J. Chem. Commun., 2011, 47, 5611.

29. Kodomari, M.; Satoh, A.; Nakano, R.; Aoyama, T. Synth. Commun. 2007, 37, 3329.

30. Marsden, S. P.; McGonagle, A. E.; McKeever-Abbas, B. Org. Lett. 2008, 10, 2589.

31. Ackermann, L.; Barfüsser, S.; Pospech, J. Org. Lett. 2010, 12 , 724.

32. Kidwai, M.; Bansal, V.; Saxena, A.; Aerry, S.; Mozumdar, S. Tetrahedron Lett. 2006, 47, 8049.

33. Lee, J. J.; Kim, J.; Jun, J. M.; Lee, B. M; Kim, B. H. Tetrahedron 2009, 65, 8821.

34. Wei1,C.-X.; Guan, L. P.; Jia, J. H.; Chai, K. Y.; Quan, Z.-S. Arch. Pharm. Res. 2009, 32, 23.

35. Erker, T. Liebigs Ann. Chem. 1989, 6, 601.

36. Kim, Y.; Kumar, M. R.; Park, N.; Heo, Y.; Lee, S. J. Org. Chem. 2011, 76, 9577.

37. Sharghi, H.; Beyzavi, M. H.; Doroodmand, M. M. Eur. J. Org. Chem. 2008, 4126.

38. Yang, D.; Fu, H.; Hu, L.; Jiang, Y.; Zhao, Y. J. Org. Chem. 2008, 73, 7841.

39. Blacker, J.; Farah, M. M.; Hall, M. I.; Marsden, S. P.; Saidi, O.; Williams, J. M. J. Org. Lett. 2009, 11, 2039.

40. Adharvana Chari, A; Shobha, M. D.; Sasaki, T. Tetrahedron Lett. 2011, 52, 5575.

41. Kim, Ja.; Kim, Je.; Lee, H.; Lee, B. M; Kim, B. H. Tetrahedron 2011, 67, 8027. 